\title{
Earthquakes Occurrence on the East African Coast and Their Implication on Stress Drop along the Davie Ridge of the East African Rift System (EARS)
}

\author{
Josphat K. Mulwa \\ Department of Geology, University of Nairobi, Kenya \\ Received May 15, 2020; Revised June 24, 2020; Accepted July 1, 2020
}

Copyright $@ 2020$ by authors, all rights reserved. Authors agree that this article remains permanently open access under the terms of the Creative Commons Attribution License 4.0 International License

\begin{abstract}
The Davie Ridge (also known as Davie fracture zone), considered as the seaward extension of eastern branch (Kenya Rift Valley) of the East African Rift System [1,2], is a $2200 \mathrm{~km}-$ long prominent relic fracture zone that cuts across the West Somali Basin [3-5]. It ranges between 30 and $120 \mathrm{~km}$ wide, with a west-facing scarp along the lower half of its length [2,6]. Earthquakes as deep as $40 \mathrm{~km}$ have been recorded below the Davie Ridge. However, recent seismic data shows that $\mathrm{M}_{\mathrm{w}} 4.0 \quad-5.0$ earthquakes at crustal depths $(10 \leq \mathrm{d} \leq 30 \mathrm{~km})$ are common. Since early 2018-2019, the Davie ridge has been characterized by high frequency of $4.4 \leq \mathrm{M}_{\mathrm{w}} \leq 5.4$ earthquakes occurrence. The purpose of the present research is to evaluate the stress drop along the Davie ridge using an empirical exponential relationship developed for $\mathrm{M}_{\mathrm{w}}$ and fault parameters (length, width and rupture area) for the East African region and compare the results to those obtained from conventional body wave inversion. The results of this study show that, using empirical exponential relation, the stress drop, $\Delta \sigma$, and the corresponding fault (rupture) area, $\mathrm{S}^{2}$, ranges between 0.49-0.78 $\mathrm{MPa}$ and $15.7-32.5 \mathrm{~km}^{2}$ respectively. Fault rupture area and stress drop results based on body wave inversion and empirical exponential equations for $\mathrm{M}_{\mathrm{w}}<6.0$ are very similar. For $\mathrm{M}_{\mathrm{w}} \geq 6.0$, however, the fault rupture area is under-estimated and this tends to over-estimate the stress drop. Empirical exponential relations offer a rapid estimate
\end{abstract}

of fault parameters and stress drop for $\mathrm{M}_{\mathrm{w}} \leq 6.0$ earthquakes.

Keywords Earthquakes, Davie Ridge, Empirical Exponential Relation, Fault Parameters, Stress Drop

\section{Introduction}

The Davie Ridge, also known as Davie Fracture Zone, has been considered as the seaward extension of eastern branch (Kenya Rift Valley) of the East African Rift System (EARS) [1,2]. The Davie ridge is a $2200 \mathrm{~km}$-long prominent relic fracture zone (Figure 1) cutting across the West Somali Basin [3-5]. 


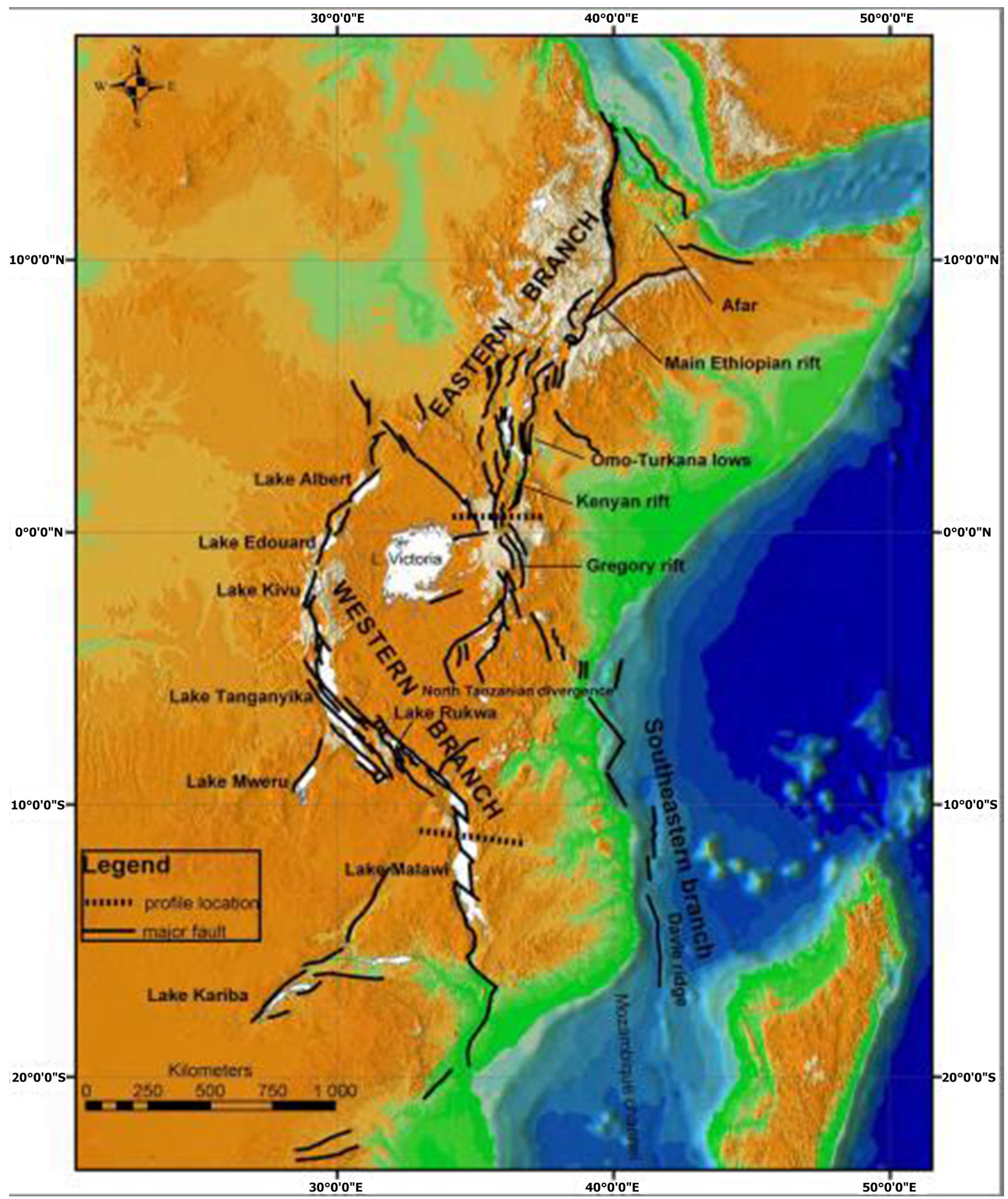

Figure 1. Seaward extension of the Eastern branch (Kenya Rift Valley) of the East African Rift system. After [1]

It ranges between 30 and $120 \mathrm{~km}$ wide, with a west-facing scarp along the lower half of its length, that rises as much as 2300 meters above the sea floor [2,6].

Earthquakes as deep as $40 \mathrm{~km}$ have been recorded along the Davie Ridge with the largest earthquake sequence (mb upto 6.4 and $\mathrm{M}_{\mathrm{o}}$ upto 5.0E18) occurring during May and June 1985 off the coast of Tanzania-Mozambique border [5]. Evaluation of recent seismic data for the purpose of this study however shows that Mw 4.0-5.0 earthquakes at relatively shallow depths of $10-20 \mathrm{~km}$ are a common occurrence along the Davie Ridge and Mozambique channel. The earthquake focal mechanism indicates that the Davie ridge is characterized by normal faulting with occasional oblique slip faulting. Seismic reflection, gravity and magnetic data from offshore East Africa allow the Davie Ridge (Fracture Zone) to be traced from $11^{\circ} \mathrm{S}$ to its intersection with the Kenyan coast at $2^{\circ} \mathrm{S}$ (Figure 2), constraining the relative motion of Madagascar and Africa [4]. Faults and fractures, probably associated with the Davie ridge (Fracture zone), have been mapped using 
gravity and magnetic data between latitudes $2^{\circ} 21^{\prime} \mathrm{S}$ and $3^{\circ} 03^{\prime} \mathrm{S}$ and longitudes $40^{\circ} 08^{\prime} \mathrm{E}$ and $40^{\circ} 45^{\prime} \mathrm{E}$ by [7].

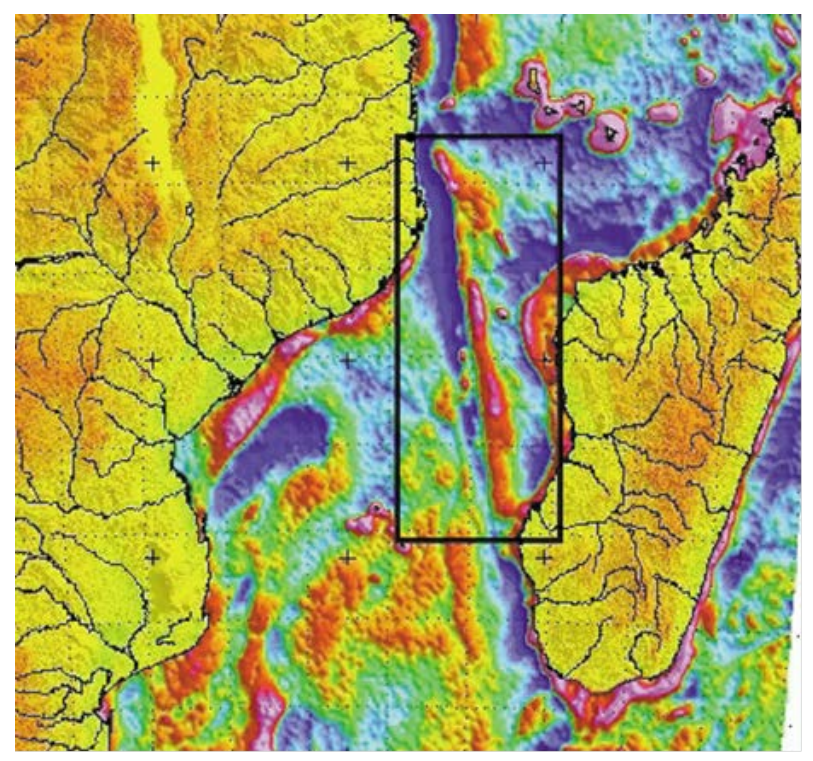

Figure 2. Satellite derived free-air gravity anomaly of the Davie Ridge/Fracture Zone enclosed in box (After [8]

\section{Materials and Methods}

\subsection{Review of Seismicity and Seismic Hazards}

The eastern branch of the East African Rift System (EARS), the Kenya rift valley, and the Davie ridge are characterized by moderate level of seismicity. Small magnitude $(M \leq 3)$ earthquakes described by [9] as earthquake swarms are common in eastern branch (Kenya rift) of EARS. In comparison to EARS, the Kenya rift shows a low seismicity. Major earthquakes in Kenya include the $1928 \mathrm{M}_{\mathrm{s}} 6.9$ in central Kenya rift valley, an aftershock $\mathrm{M}_{\mathrm{s}}$ 6.0, as well as the $1913 \mathrm{M}_{\mathrm{s}} 6.0$ Turkana region earthquake [10,11].

Mulwa et al., [12] have assessed tsunami hazard potential on the East African coast due to earthquake occurrence along the Davie ridge using three earthquake scenarios of $\mathrm{M}_{\mathrm{w}}$ 7.2, 8.0 and 9.0 and fault parameters (rupture length, width, and surface displacement/fault dislocation) derived from [13]. Table 1 summarizes fault parameters as well as the associated sea floor displacement and tsunami wave heights for the three earthquake scenarios.

Table 1. Fault parameters and associated sea floor displacement (m) and tsunami wave height $(\mathrm{m})$ due to three earthquake scenarios along the Davie Ridge (After [12]).

\begin{tabular}{cccccccc}
\hline $\mathrm{M}\left(\mathrm{M}_{\mathrm{w}}\right)$ & Strike* & Dip*(West) & Slip $(\mathrm{m})$ & $\begin{array}{c}\text { Length } \\
(\mathrm{km})\end{array}$ & $\begin{array}{c}\text { Width } \\
(\mathrm{km})\end{array}$ & $\begin{array}{c}\text { Sea floor } \\
\text { displacement }(\mathrm{m})\end{array}$ & $\begin{array}{c}\text { Maximum tsunami } \\
\text { wave height }(\mathrm{m})\end{array}$ \\
\hline 7.2 & $0^{\circ}$ & $70^{\circ}$ & 3.5 & 60 & 35 & $\leq 0.5$ & 1.0 \\
8.0 & $0^{\circ}$ & $70^{\circ}$ & 7.6 & 200 & 50 & $\leq 3.0$ & 5.0 \\
9.0 & $0^{\circ}$ & $70^{\circ}$ & 20.0 & 1200 & 200 & $\leq 10.0$ & 10.0 \\
\hline
\end{tabular}

*Values of strike and dip are adapted from continental studies of the Kenya rift valley e.g. [19,20] 


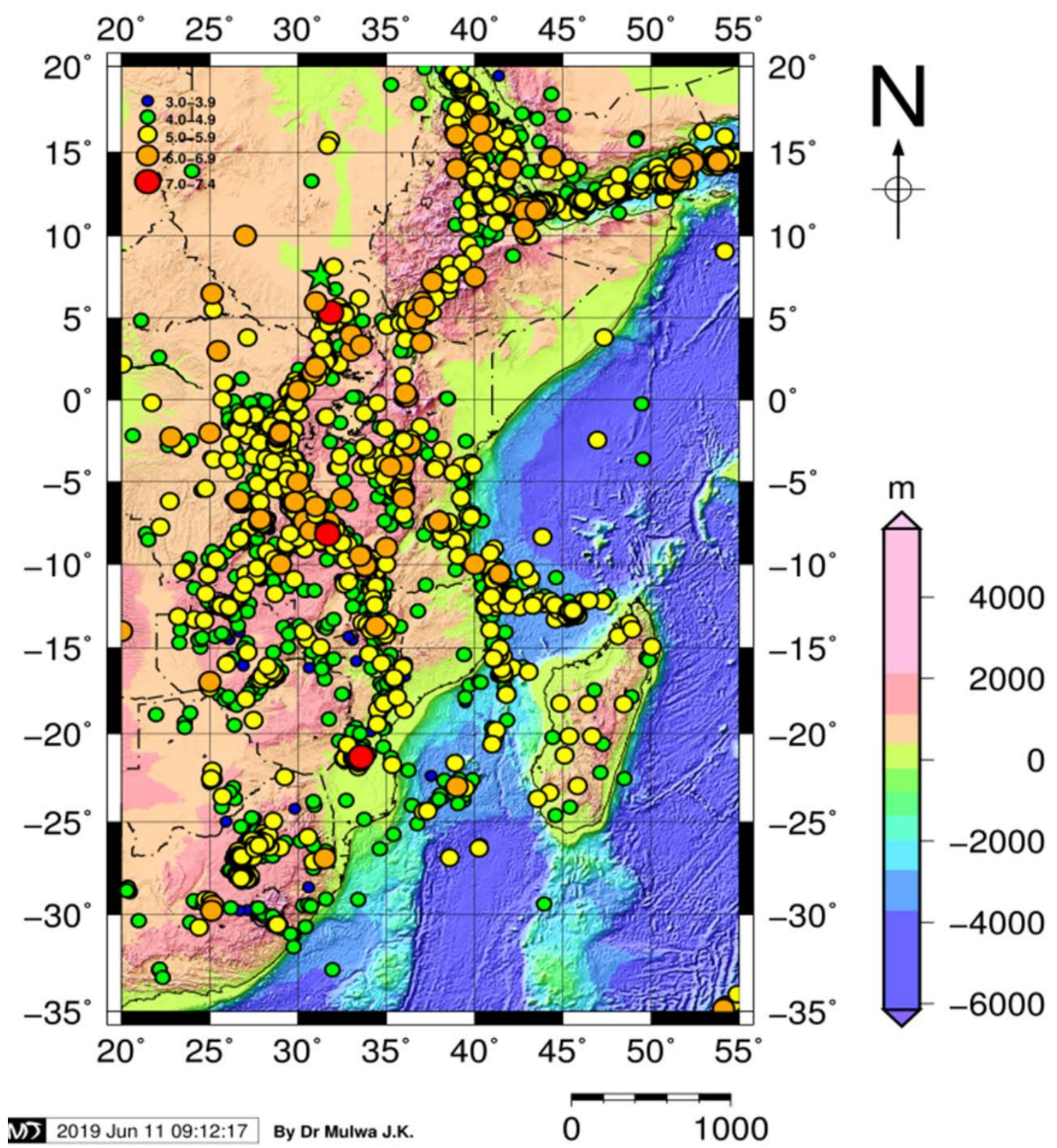

Figure 3. Distribution of earthquake epicenters on the eastern part of Africa from 1900 - May 2019 for $\left(\mathrm{M}_{\mathrm{w}} \geq 3.5\right)$.

\subsection{Earthquake Data}

Subscription of the International Data Centre (IDC) SEL1 and REB products as well as supplementary earthquake data from International Seismological agencies/sources e.g. ISC, GFZ, USGS, NEIC e.t.c. has allowed continuous monitoring of earthquakes occurrence along the Davie ridge. For a period from 2018 to 2019, the Davie ridge has been characterized by high frequency of earthquakes occurrence. Figures 3 and 4 show the distribution earthquake epicenters on the eastern part of Africa including the Davie Ridge and the Mozambique channel from 1900-May 2019, and for the period January 2018 to May 2019 for $\mathrm{Mw} \geq 3.5$, respectively.

In order to assess the stress drop along the Davie Ridge, moment magnitudes $\left(\mathrm{M}_{\mathrm{w}}\right)$ from the various seismological agencies, in addition to fault parameters by [13] have been used. Seismic moment $M_{0}(\mathrm{Nm})$ required for stress drop computation was calculated from the standard relationship between moment magnitude and seismic moment $[14,15]$. The fault rupture area, which is required for stress drop computation, for the respective moment magnitudes of earthquakes along the Davie ridge was determined from [13] using an empirical exponential relationship between fault parameters (fault length, width and rupture area) versus magnitude. These fault parameters have previously been determined based on empirical relationships, regression curves and coefficients as discussed by $[13,16,17]$. Figure 5 shows a plot of fault rupture area versus moment magnitude along the Davie ridge and the 
empirical exponential relationship used in this study.

The stress drop along the Davie ridge was then computed based on the equation below by [18].

$$
\Delta \sigma=2.5 M_{O} / S^{1.5}
$$

where $\Delta \sigma$ is the stress drop, $M_{0}$ is the seismic moment and $\mathrm{S}$ is the fault rupture area associated to a particular moment magnitude. Table 2 shows the moment magnitudes and the associated fault rupture area and stress strop along the Davie ridge.
Table 2. Moment magnitudes and the associated fault rupture area and stress drop calculated during this study

\begin{tabular}{ccc}
\hline $\begin{array}{c}\text { Moment magnitude } \\
(\mathbf{M w})\end{array}$ & $\begin{array}{c}\text { Fault rupture area } \\
\mathbf{( k m}^{\mathbf{2}} \mathbf{n}\end{array}$ & $\begin{array}{c}\text { Stress drop } \\
\mathbf{( M p a )}\end{array}$ \\
\hline 4.7 & 15.7 & 0.49 \\
4.9 & 23.4 & 0.63 \\
5.1 & 32.5 & 0.78 \\
6.0 & 143.9 & 2.03 \\
6.5 & 313.3 & 3.34 \\
7.0 & 673.2 & 5.44 \\
7.2 & 933.7 & 6.70 \\
\hline
\end{tabular}

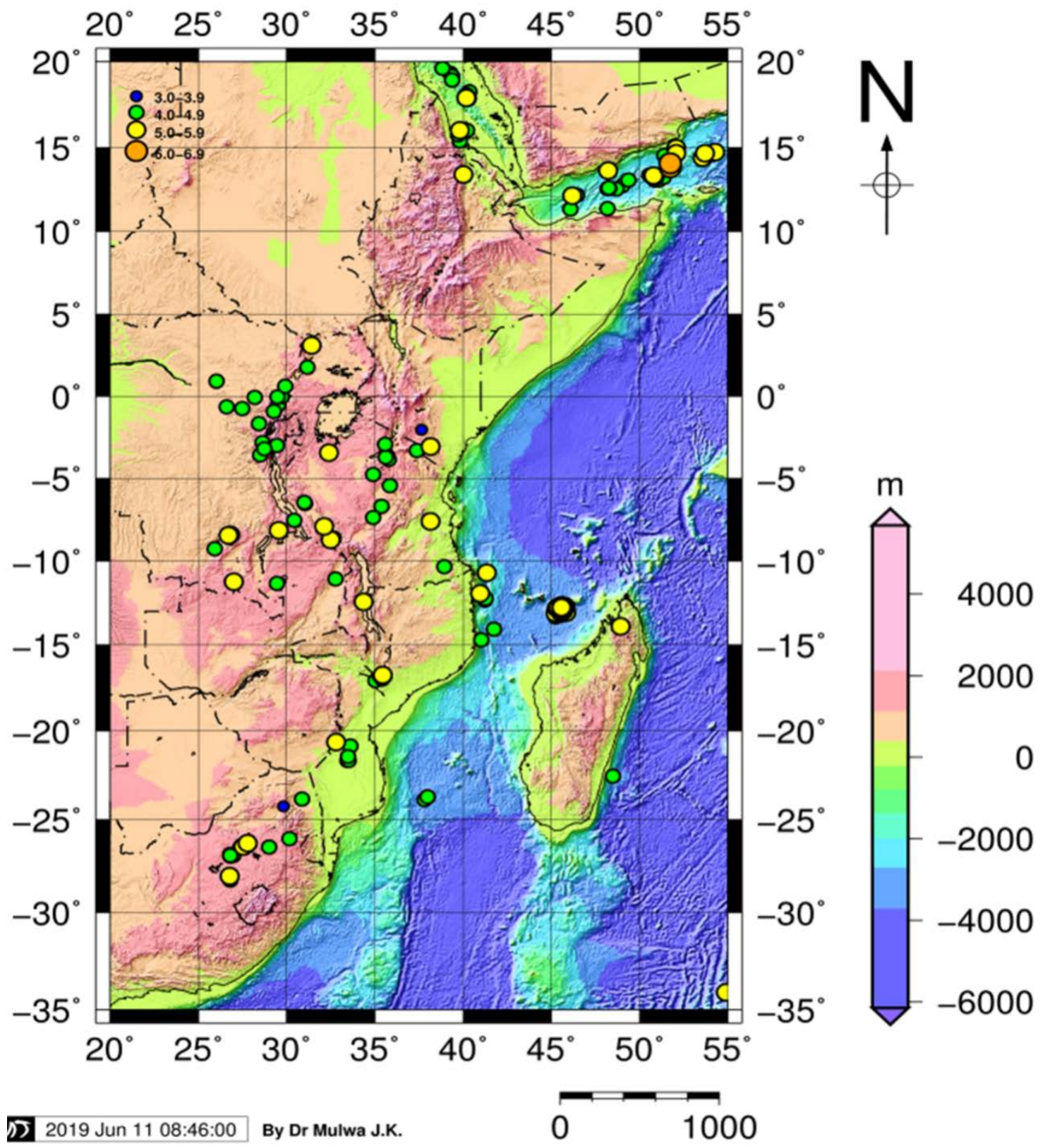

Figure 4. Distribution of earthquake epicenters on the eastern part of Africa for the period 2018-May 2019 (Mw $\geq 3.5)$ 


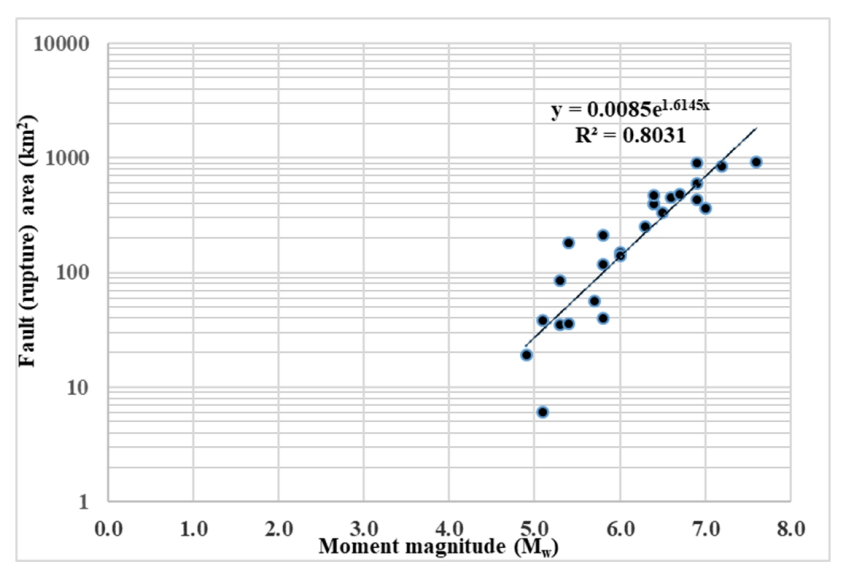

Figure 5. Fault rupture area $\left(\mathrm{km}^{2}\right)$ versus moment magnitude $\left(\mathrm{M}_{\mathrm{w}}\right)$ along the Davie ridge

\section{Results}

The distribution of earthquake epicenters in Figure 4 shows that, out of a total of 364 events during the period from 2018 to May 2019, 222 events (61\%) have occurred along the Davie Ridge (7) and Northwest of Madagascar (215). The magnitude $\left(M_{w}\right)$ ranges between 4.4-5.4 and 4.4-5.9 respectively. Along the Davie Ridge, the estimated fault (rupture) area ranges between $15.7-32.5 \mathrm{~km}^{2}$ for the lower and higher bound magnitudes respectively, and the corresponding stress drop ranges between 0.49-0.78 MPa.

\section{Discussion}

Empirical relationships, regression curves and coefficients under-estimate the fault rupture area and subsequently over-estimate the stress drop for magnitudes above a certain limit. The results from this study have been compared with previous works e.g. Mulwa [21], Mulwa and Kimata [22], [23,24] among others, who have used teleseismic body wave inversion to retrieve seismic moment and fault parameters and subsequently used these to compute the associated stress drop.

For teleseismic body wave inversion of the May 20, $1990 \mathrm{M}_{\mathrm{w}}$ 7.2 South Sudan earthquake, Mulwa [21) and Mulwa and Kimata [22] obtained seismic moment and fault rupture area of $7.65 \mathrm{E}+19 \mathrm{Nm}$ and $2400 \mathrm{~km}^{2}$ respectively. The calculated stress drop due to the May 20, 1990 South Sudan earthquake was 1.63 MPa. Using the empirical exponential relationship obtained in the present study, the calculated fault rupture area and stress drop are respectively $933.7 \mathrm{~km}^{2}$ and $6.70 \mathrm{MPa}$. This overly under-estimates the rupture area but over-estimates the stress drop by about 5.1 MPa.

Results of seismic body wave inversion of the October 12, $1992 \mathrm{M}_{\mathrm{w}} 5.8$ Cairo earthquake by [23], however, show that the fault rupture area and stress drop are somewhat quite similar to those obtained using empirical exponential relation apart from slight over-estimate of rupture area and under-estimate of stress drop using the latter method. [23] obtained values of $99 \mathrm{~km}^{2}$ and $1.85 \mathrm{MPa}$ from body wave inversion. The results using the empirical exponential relation are, however, $105.5 \mathrm{~km}^{2}$ and $1.66 \mathrm{MPa}$ respectively. These results do not differ significantly from those using seismic body wave inversion.

Reference [24] inverted $\mathrm{P}$ and $\mathrm{SH}$ body waves to determine the source processes of the $1994 \mathrm{M}_{\mathrm{w}} 6.6$ earthquake and its aftershocks. The inversion results show that the fault rupture area is approximately $600 \mathrm{~km}^{2}$ and the seismic moment is $1.1 \mathrm{E}+19 \mathrm{Nm}$. Using these values, the calculated stress drop is $1.87 \mathrm{MPa}$. From the empirical exponential relation, however, the rupture area is 377.1 $\mathrm{km}^{2}$ and the associated stress drop is 3.76 MPa.

The August 3, 1993 and November 22, $1995\left(M_{s} 7.2\right)$ earthquakes occurred in the Dead Sea fault system (DSFS) with the 1995 event originating in the vicinity of the 1993 event and propagating northwards where seismic moment releases $\left(\mathrm{M}_{0}=7.4 \mathrm{E} 18\right.$ and 38E18) due to two sub-events took place [25]. Inversion results of teleseismic body waves for the 1995 event show that the stress drops due to the two sub-events are 1.2 MPa and 2.0 MPa respectively. Empirical exponential relation however gives stress drops of 3.34 MPa and 5.44 MPa respectively. These values of stress drops obtained using the empirical exponential relation are as well slightly overestimated due to probably an under-estimation of the fault rupture area. For the 1993 earthquake, however, seismic moment release of 1.4E18 equivalent to $M_{w} 6.0$, the stress drops from seismic body wave inversion and empirical exponential relation are 3.5 $\mathrm{MPa}$ and 2.03 MPa respectively. As the earthquake magnitude for this event is very close to that of [23], the stress drops obtained from teleseismic body wave inversion and empirical exponential relation do not significantly differ. This would support the fact that fault rupture area and stress drop for $\mathrm{M}_{\mathrm{w}}<6.0$ obtained using the empirical exponential relations and waveform inversion are very close.

\section{Conclusions}

Earthquake magnitudes have a strong bearing on the fault parameters and stress drop. The results obtained from this study show that fault rupture area and stress drop results obtained from body wave inversion and empirical exponential equations for earthquake magnitudes of $\mathrm{M}_{\mathrm{w}} \leq 6.0$ are very similar.

Conversely, stress drop obtained based on fault parameters using empirical exponential relationships, regression curves and coefficients e.g. $[13,16,17]$ and Mulwa (this article) are overestimated for $M_{w}>6,0$. For such $\mathrm{M}_{\mathrm{w}}>6.0$, the fault rupture area is overly under-estimated and this tends to over-estimate the stress drop. 
Nevertheless, the empirical exponential relationships, equations, curves and coefficients offer a rapid estimate of fault parameters and stress drop.

This paper recommends teleseismic body-wave inversion/waveform modeling method e.g. [18,21-29] e.t.c to retrieve source (fault) parameters, seismic moment and use these for computation of the associated stress drop especially for $\mathrm{M}_{\mathrm{w}}>6.0$.

\section{REFERENCES}

[1] J. Chorowicz. The East African rift system, Journal of African Earth Sciences, Vol. 43, 379-410, 2005.

[2] D. Mougenot, M. Recq, P. Virlogeux, C. Lepvrier. Seaward extension of the East African Rift, Nature, Vol. 321, 599-603, 1986.

[3] M. F. Coffin, P. D. Rabinowitz. Reconstruction of Madagascar and Africa; evidence from the Davie Fracture Zone and Western Somali Basin. Journal of Geophysical Research, Vol. 92, B9, 9385-9406, 1987.

[4] M. F. Coffin, P. D. Rabinowitz. Evolution of the conjugate East African-Madagascan margins and the western Somali Basin, The Geological Society of America, Boulder, Special Paper, Vol. 226, 1-78, 1988.

[5] N. L. Grimison, W. P. Chen. Earthquakes in the Davie Ridge-Madagascar Region and the Southern Nubian-Somalian Plate Boundary, Journal of Geophysical Research, Vol. 93, B9, 10,439-10,450, 1988.

[6] R.A. Scrutton. Davie Fracture Zone and the movement of Madagascar, Earth and Planetary Science Letters, Vol. 39, 84-88, 1978.

[7] Gippsland Offshore Petroleum Ltd. Gravity and magnetic surveys in the Lamu embayment. Unpublished Report, 2009.

[8] D. Bird. Shear margins: Continent-ocean transform and fracture boundaries, The Leading Edge, February 2001, 150-159, 2001.

[9] M. Ibs-von Seht, S. Blumenstein, R. Wagner, D. Hollnack, J. Wohlenberg. Seismicity, seismotectonics and crustal structure of the southern Kenya rift - new data from the Lake Magadi area, Kenya, Geophysical Journal International, Vol. 146, 439-453, 2001.

[10] N. N. Ambraseys. Earthquake hazard in the Kenya Rift: the Subukia earthquake 1928. Geophysical Journal International, Vol. 105, 253-269, 1991.

[11] N. N. Ambraseys, R. D. Adams. Reappraisal of Major African Earthquakes, South of $20^{\circ} \mathrm{N}, 1900-1930$. Natural Hazards, Vol. 4, 389-419, 1991.

[12] J. K. Mulwa, F. Kimata, A. D. Nguyen. Seismic hazards in Kenya. In: Paron, P., Olago, D.O., Omuto, C.T. (eds.) Kenya: A natural outlook; Developments in Earth Surface Processes, Elsevier B.V, Netherlands, Vol. 16, 267-293, 2013.

[13] D. L. Wells, K. J. Coppersmith. New Empirical Relationships among Magnitude, Rupture Length, Rupture
Width, Rupture Area, and Surface Displacement. Bull. Seismological Soc. of America, Vol. 84, No. 4, 974-1002, 1994.

[14] H. Kanamori. The energy release in great earthquakes. Journal of Geophysical Research, Vol. 82, 2981-2987, 1977.

[15] T. C. Hanks, H. Kanamori. A moment magnitude scale. Journal of Geophysical Research, Vol. 84, 2348-2350, 1979.

[16] B. G. Papazachos, E. M. Scordilis, D. G. Panagiotopoulos, C. B. Papazachos, G. F. Karakainis. Global relations between seismic fault parameters and moment magnitude of earthquakes, Bulletin of Geological Society of Greece, Vol. XXXVI, 1482-1489, 2004

[17] A. V. Vakov. Relationship between earthquake magnitude, source geometry and slip mechanism, Tectonophysics, Vol. 261, 97-113, 1996.

[18] Y. Fukao, M. Kikuchi. 87). Source retrieval for mantle earthquakes by iterative deconvolution of long-period P-waves, Tectonophysics, Vol. 144, 249-269, 1987.

[19] I.O. Nyambok. Hydrogeology and geochemistry of groundwater resources of the Central Rift of Kenya. Proc. Regional workshop on research for sustainable water resources in East African Rift Valley, Addis Ababa, Ethiopia, 1-16, 2001.

[20] P. A. Omenda, P.A., 1994. The geological structure and reservoir characteristics of the Olkaria West geothermal field. Proc. Stanford Geothermal Reservoir Eng. Workshop, 125-130, 1994.

[21] J. K. Mulwa. Determination of source parameters for the May 20, 1990 South Sudan earthquake by inversion of teleseismic body-waves. In: JICA Training programme, "Operating Management of Earthquake, Tsunami and Volcano Eruption Observation System”, Fiscal Year 2010. Research Center for Seismology, Volcanology and Disaster Mitigation, Graduate School of Environment Studies, Nagoya University/Chubu International Center, Japan International Cooperation Agency, Japan, 15-31, 2010.

[22] J. K. Mulwa, F. Kimata. Tectonic structures across the East African Rift based on the source parameters of the 20 May 1992 M7.2 Sudan earthquake, Natural Hazards, Vol. 73, 493-506, 2014.

[23] H. M. Hussein. Source process of the October 12, 1992 Cairo earthquake, Annali Di Geofisica, Vol. 42, No. 4, 665-674, 1999.

[24] H. K. Thio, H. Kanamori. Source complexity of the 1994 Northridge earthquake and its relation to aftershock mechanisms, Bulletin of Seismological Society of America, Vol. 86, No. 1B, S84-S92, 1996.

[25] A. Pinar, N. Türkelli. Source inversion of the 1993 and 1995 Gulf of Aqaba earthquakes, Tectonophysics, Vol. 283, 279-288, 1997.

[26] S. Tsuboi, M. Kikuchi, Y. Yamanaka, M. Kanao. The March 25, 1998 Antarctica earthquake: Great earthquake caused by postglacial rebound, Earth Planets Space, Vol. 52, 131-136, 2000.

[27] M. Kikuchi, H. Kanamori. Source characteristic of the 1992 Nicaragua tsunami earthquake inferred from teleseismic body waves, Pure and Applied Geophys, Vol. 144, No. 3/4, 
442-453, 1995.

[28] D. Giardini, L. Beranzoli. Waveform modeling of the May 20, 1990 Sudan earthquake, Tectonophysics, Vol. 209, 105-114, 1992.
[29] H. Kanamori, J. W. Given. Use of long-period surface waves for rapid determination of earthquake-source parameters, Physics of the Earth and planetary interiors, Vol. 27, 8-31, 1981. 